\title{
Effect of Potassium Lactate and Sodium Diacetate Combination to Inhibit Listeria Monocytogenes In Low and High Fat Chicken and Turkey Hotdog Model Systems
}

\author{
A. V. S. Perumalla ${ }^{1}$, Navam. S. Hettiarachchy*1,2 ${ }^{1,}$ Kenneth. F. Over ${ }^{3}$, Steven. C. Ricke ${ }^{1,2}$, Edward. \\ E. Gbur ${ }^{4}$, Jinying Zhang ${ }^{4}$ and Brad Davis ${ }^{3}$ \\ ${ }^{1}$ Department of Food Science, University of Arkansas, Fayetteville, AR 72704, USA \\ ${ }^{2}$ Center for Food Safety, Dept. of Food Science, University of Arkansas, Fayetteville, AR 72704, USA \\ ${ }^{3}$ Tyson Foods Inc., Springdale, AR 72764, USA \\ ${ }^{4}$ Agricultural Statistics Laboratory, University of Arkansas, Fayetteville, AR 72701, USA
}

\begin{abstract}
Effect of potassium lactate (PL) and sodium diacetate (SD) combinations at varying levels were evaluated in low (5\%) and high (20\%) fat chicken and turkey hotdog model systems. All the samples were surface inoculated with Listeria monocytogenes (approximately $4.6 \mathrm{log} \mathrm{cfu} / \mathrm{g}$ ), vacuum packed and stored at $4{ }^{\circ} \mathrm{C}$ for 28 days to determine the effective combination of PL and SD and the effect of fat content on the growth inhibition of L. monocytogenes. In chicken hotdog samples, maximum growth inhibitions ( $3.4 \mathrm{log} \mathrm{cfu} / \mathrm{g}$ ) were observed in low fat samples formulated with $3.0 \%$ PL and $0.15 \% \mathrm{SD}$. In turkey hotdog samples, maximum growth inhibitions (3.3 log cfu/g) were observed in low fat samples formulated with 3.0\% PL and $0.2 \%$ SD. Effective combination levels determined in low and high fat chicken were $3.0 \%$ PL and $0.15 \% \mathrm{SD}$, whereas in low and high fat turkey, the effective levels were $3.0 \% \mathrm{PL}$ and $0.20 \% \mathrm{SD}$. Overall, fat content had significant effect $(P<0.05)$ on growth inhibition as indicated by higher inhibitions in low fat chicken and turkey hotdogs than high fat samples. These results demonstrate that commercial usage levels of PL (2.0\%) and SD (0.15\%) alone are not sufficient to control L. monocytogenes in case of pathogen contamination.
\end{abstract}

Keywords: Fat content, Hotdogs, Listeria monocytogenes, Potassium Lactate, Sodium Diacetate.

\section{INTRODUCTION}

Listeria monocytogenes (L. monocytogenes) is the most common post-processing bacterial contaminant in ready-toeat (RTE) meat and poultry products and has elicited intense concerns to consumers and processors due to recurrent outbreaks resulting in associated product recalls [1]. Among the RTE foods contaminated by $L$. monocytogenes, deli meats and non-reheated hotdogs poses "very high risk" per serving risk of illness/death [2]. As a result, the U.S. Dept. of Agriculture (USDA) and Food and Drug administration (FDA) maintains a "zero tolerance" (no detectable levels permitted) policy for L. monocytogenes in RTE products [3].

Based on the public health significance and treatment costs, there is a need to develop effective intervention strategies to inhibit or kill the pathogens that would improve the microbiological quality of the meat [4]. Control measures for safety of RTE poultry products should include reducing the risk of contamination as well as inhibiting the growth of pathogens during handling and storage. Conventional chemical antimicrobials such as lactates and diacetates act as bacteriostatic agents against foodborne pathogens including $L$. monocytogenes in meat and poultry products.

*Address correspondence to this author at the Department of Food Science \& Institute of Food Science and Engineering, 2650 N. Young Ave, Dept. of Food Science, Fayetteville, AR, 72704, USA; Tel: (479) 575-4779;

Fax: (479) 575-6936; E-mail: nhettiar@uark.edu
Potassium lactate (PL) is a clear syrupy liquid derived from lactic acid and acts as bacteriostatic agent by extending the lag phase or dormant phase of pathogens and thereby prolonging the shelf life of the food products [5]. The specific mechanisms of actions of lactates are: (1) reducing the water activity $\left(\mathrm{a}_{\mathrm{w}}\right)$ of the product [6] and (2) intracellular acidification [7]. Sodium diacetate (SD) is bactericidal in action against $L$. monocytogenes by lowering the intracellular $\mathrm{pH}$ and thereby significantly inhibiting the growth of the initial bacterial load [8]. Both PL and SD are FDA approved and classified as GRAS (Generally Recognized as Safe) ingredients in RTE meat and poultry products [9]. Maximum permissible levels of lactates (60\% lactate solution) and diacetates used in the meat formulations are $4.8 \%$ and $0.25 \%$ respectively, based on the batch weight of total formulation [10]. However, higher concentration levels of lactates $(>3$ $\%)$ affect sensory properties [11]. The maximum level for sodium diacetate from a flavor perspective is 0.1 to $0.15 \%$, whereas its inhibitory effects become apparent from $0.125 \%$ [12]. At $0.20 \%$ concentration, it has a negative effect on odor and taste of the product [5]. Combination of these two antimicrobials have demonstrated enhanced inhibition of the growth of L. monocytogenes on RTE meats during long-term refrigerated storage than when used alone [13].

Antimicrobial activity of any preservative depends on their hydrophilic and hydrophobic properties i.e. solubility in water and fat, distribution in the model system, fat content, 
$\mathrm{pH}$ and temperature [14]. Effective combinations of lactates and diacetates varies from one product to another as influenced by difference in meat matrices, formulations (types of meat, moisture and fat content, water activity, $\mathrm{pH}$, salt and nitrite levels), storage temperature and packaging conditions $[15,16]$. In addition, in biphasic foods such as hotdogs (oilin-water emulsion), food structure and lipid component may have a controlling influence on growth of the pathogen by its tendency to redistribute chemical components between phases of foods and controlling the concentration of undissociated antimicrobial compounds in the aqueous phase [17]. As the undissociated form of organic acid is lipophilic, less of the undissociated acid or antimicrobial may localize in the aqueous phase and hence can affect their efficacies [18]. Furthermore, between the chicken and turkey meat, variation in protein and fatty acid profiles exist [19].

To our knowledge, there is no published literature on the influence of fat content on the growth of $L$. monocytogenes in presence of lactate and diacetate combinations in chicken and turkey hotdog formulations. Therefore, the main purpose of this study was to determine the effective combination of PL and SD to inhibit the growth of L. monocytogenes in surface inoculated low and high fat chicken and turkey hotdog model systems.

\section{MATERIALS AND METHODS}

\section{Materials}

Mechanically separated chicken and fresh, boneless, skinless chicken breast (Tyson Foods Inc, Springdale, AR, USA) and mechanically deboned turkey (Cargill Meat Solutions, Springdale, AR, USA) were used to prepare low and high fat chicken and turkey hotdogs. Non-meat ingredients for hotdog preparation included salt, sodium tripolyphosphate, dextrose, monosodium glutamate, (Heartland Supp. Co, AR, USA), red pepper, black pepper (Eatem Foods Company, NJ, USA), sodium nitrite (Southern Indiana Butcher Supply, IN), potassium lactate (PURASAL ${ }^{\circledR} 60 \%$ HiPure P, Purac America, Lincolnshire, IL) and sodium diacetate (Jarchem, NJ, USA). Non-edible casings were used to stuff the emulsified meat (Casings: $30 \mathrm{~mm}$ diameter fibrous cellulose casings; E-Z Peel4 Nojax, 30-84 4STR clear, Viskase Corp., Willowbrook, IL, USA). Oxford Listeria selective agar was used to isolate Listeria monocytogenes (EMD Chemicals Inc., Gibbstown, NJ, USA).

\section{Methods}

\section{Hotdog Preparation}

High fat $(20 \%$ fat in final product) hotdogs were formulated using mechanically separated chicken or turkey meat, whereas the low fat ( $5 \%$ fat in final product) hotdogs were formulated using ground boneless, skinless chicken breast meat or mechanically separated turkey meat. Non-meat ingredients used in preparation of low and high fat chicken and turkey hotdogs included ice, salt, sodium tripolyphosphate, dextrose, sodium nitrite, dextrose, red and black pepper, and monosodium glutamate. Ground meat was mixed with nonmeat ingredients and varying levels of PL and SD combinations (Fig. 1) to form a homogenous emulsion batter in a bowl chopper (Type K64V-VA, Seydelman, Germany). The meat emulsion was transferred to a sausage stuffer (Friedrich Dick hand stuffer, 15LTR, Germany) with inedible cellulose casings (30 $\mathrm{mm}$ diameter) and slid along the horn of the stuffer. This emulsion was stuffed, extruded, pinched and twisted into 6-inch hotdogs links. Hotdogs were placed on cooking sticks in an oven (ALKAR-RapidPak, Inc, Model1000 , Wisconsin, USA) at $82.2{ }^{\circ} \mathrm{C}$ until the internal temperature reached $73.8^{\circ} \mathrm{C}$ to kill/inactivate all the foodborne pathogens. After cooking, hotdogs were showered with water at $25.5{ }^{\circ} \mathrm{C}$ and stored at $4{ }^{\circ} \mathrm{C}$ for surface inoculation and storage studies.

\section{Proximate Analysis}

Determination of percent moisture (AOAC 2000, method 985.14), protein (AOAC 2000, method 992.15), and fat (AOAC 2000, method 985.15) were conducted in the hotdogs at the start of the experiment. Eight hotdogs (noninoculated) per meat and fat type were homogenized in a food blender $\left(\right.$ Oster $^{\circledR}$ 16-speed blender; Model-6687, Sunbeam Products, Inc., FL, USA) and sampled for moisture, protein and fat analyses in triplicates.

\section{Water Activity $\left(a_{w}\right)$}

Homogenized hotdog samples were spread evenly up to half of the sample cup and positioned inside the vapour chamber of AquaLab ${ }^{\mathrm{TM}}$ analyser (Model 3 series, Decagon Devices Inc., Washington DC, USA) at $20{ }^{\circ} \mathrm{C}$ to determine the $\mathrm{a}_{\mathrm{w}}$ in triplicates.

\section{Residual Nitrite and $\mathrm{pH}$}

Residual nitrite (ppm) in hotdogs (meat and fat type) was determined in triplicate samples by colorimetric method (AOAC 2000, method 973.31). For pH determination, frankfurter samples were first stomached for $120 \mathrm{~s}$ at 8.0 strokes/s (Neutec Group Inc.191 masticator; Torrent de 1'Estadella, 22 08030 Barcelona, Spain) with distilled water $(1: 10 \mathrm{w} / \mathrm{v})$. The $\mathrm{pH}$ values were recorded by using a $\mathrm{pH}$ meter (OrionTM, model 720A, Orion Research Inc., Beverly, MA, USA) into the stirred slurry.

\section{Preparation of Bacterial Suspension}

A loopful of frozen stock (at $-70^{\circ} \mathrm{C}$ ) of Listeria monocytogenes (strain V7, serotype $1 / 2 \mathrm{a}$; FDA isolate) obtained from Center for Food Safety laboratory (Fayetteville, AR) was transferred to brain heart infusion $(\mathrm{BHI})$ broth $(10 \mathrm{~mL})$ and incubated (New Brunswick Scientific agitating incubator at $200 \mathrm{rpm}$; Edison, NJ, USA) at $37{ }^{\circ} \mathrm{C}$ for $24 \mathrm{~h}$. About $10 \mu \mathrm{L}$ of the culture was inoculated into $10 \mathrm{~mL}$ of fresh BHI, and incubated at $37{ }^{\circ} \mathrm{C}$ for $18 \mathrm{~h}$. The incubated cultures after $18 \mathrm{~h}$ were centrifuged (J2-21 Centrifuge, Beckman, Fullerton, CA, USA) at $37{ }^{\circ} \mathrm{C}$ for 10 min to obtain the supernatant and the culture pellets. The pellets were washed twice with phosphate buffer saline (PBS) and re-suspended in the volume of PBS that was equal to the original volume of BHI in the culture. Serial dilutions of the bacterial suspension were made to obtain approximately $10^{5} \mathrm{cfu} / \mathrm{mL}$ for surface inoculation of the hotdog samples.

\section{Surface Inoculation of the Hotdog Samples}

Hotdogs were sliced into cubes $\left(1.5-2 \mathrm{~g} ; 1 \mathrm{~cm}^{3}\right)$ and used for surface inoculation as described by [20]. We used 
cubed hotdog samples (for better handling and control over experimental conditions under laboratory setting) as model system instead of full hotdog for surface inoculation as demonstrated by previous studies [21]. For surface inoculation, hotdog samples were dipped into the $L$. monocytogenes cultures $\left(\sim 10^{5} \mathrm{cfu} / \mathrm{mL}\right)$ for $1 \mathrm{~min}$ and air dried for 20 min under the laminar hood that enabled the bacterial cells to attach to the surface of hotdog samples (to achieve $\sim 4.6 \log \mathrm{cfu} / \mathrm{g}$ ). A total of 588 hotdog samples [2 meat types (chicken and turkey) $\mathrm{X} 2$ fat levels (low and high) $\mathrm{X} 7$ treatments including control X 7 sampling days X 3 replications] were inoculated. After drying, each inoculated hotdog sample was transferred to a sterile whirlpak bag $\left(7.5 \times 12.5 \mathrm{~cm}^{2} ; 2.25\right.$ mil thickness and 276.CC/100 Sq Inch), vacuum packed (VacMaster-VP 215 , Portland, OR, USA) and stored at $4{ }^{\circ} \mathrm{C}$ for 28 days.

\section{Bacterial Enumeration}

Three hotdog samples per treatment were observed on each sampling day $0,4,8,12,16,21$, and 28 days to determine the inhibitory activity of PL and SD combination against the growth of $L$. monocytogenes. Phosphate buffer saline (PBS at $\mathrm{pH}$ 7.0) was added to the stomacher bags to make a 10 fold dilution and stomached for $120 \mathrm{~s}$ to form a homogenate. Stomached samples were serially diluted with

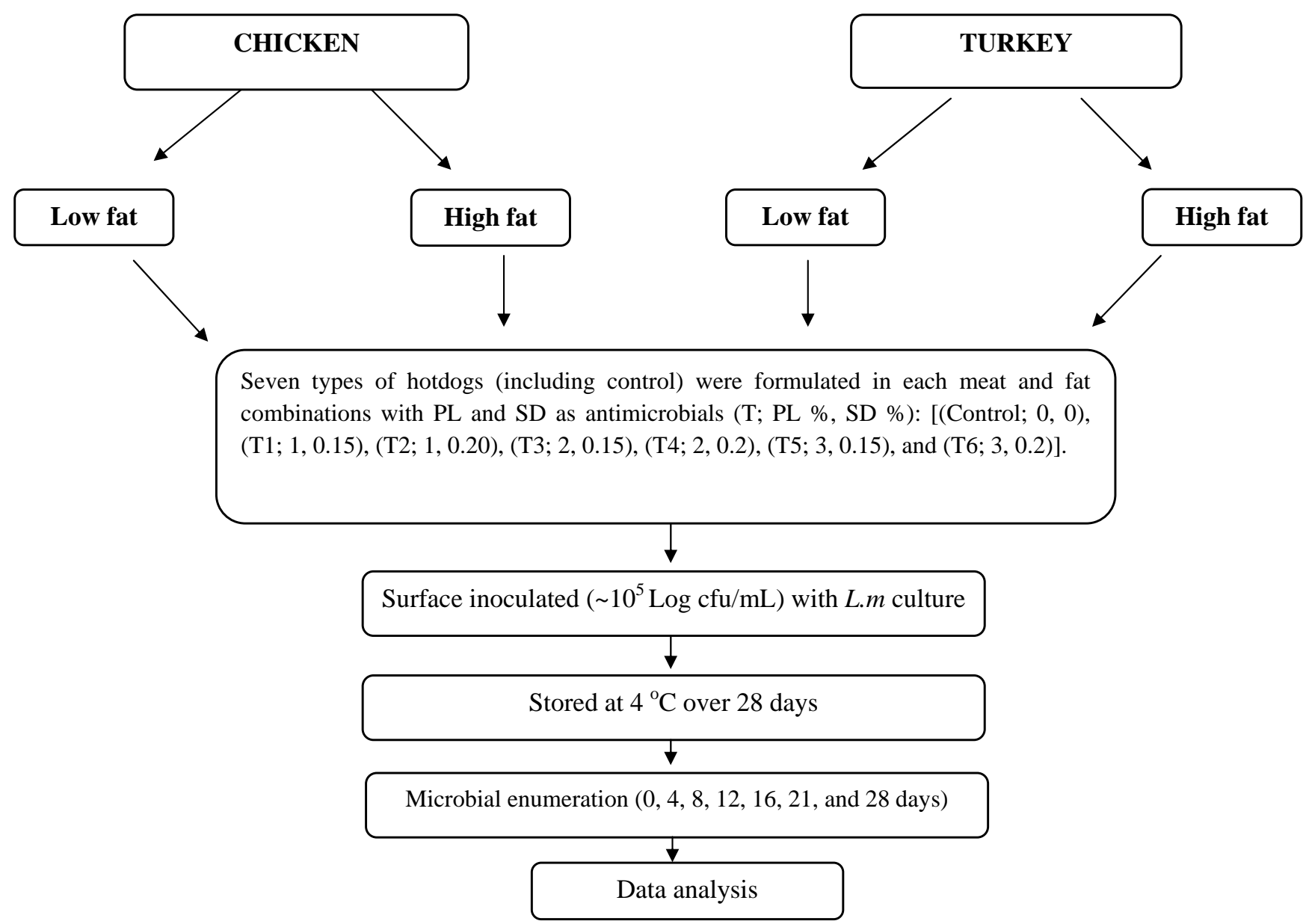

PBS, spread plated onto oxford agar with selective supplement, and incubated at $37^{\circ} \mathrm{C}$ for $48 \mathrm{~h}$ for colony enumeration.

\section{Experimental Design and Statistical Analysis}

The experiment design was a split plot where the whole plot portion was completely randomized with [two meats (chicken and turkey) $\mathrm{X}$ two fats (high and low fat) $\mathrm{X}$ seven PL-SD combinations (including control i.e. no PL and SD)] and the split-plot factor was the seven storage times $(0,4,8$, $12,16,21$, and 28 days) with three replications (3 hot dog samples at each sampling time). (Fig. 1). Observations over time (repeated measures) were considered as split-plot component and the rest of the factors (fat, meat, and treatment) as whole-plot component. For each storage time (day), growth inhibitions $(\log \mathrm{cfu} / \mathrm{g})$ were determined as the difference between mean log $(\mathrm{cfu} / \mathrm{g})$ count of the control and the mean $\log (\mathrm{cfu} / \mathrm{g})$ count of treatment sample (PL-SD combination) on that particular day. Analysis of variance was performed using PROC MIXED in SAS ${ }^{\circledR}$ version 9.2 (SAS Institute, Cary, NC, USA) and used to determine statistical differences among the main effects and their interactions with a significance level of $P<0.05$. Significant differences among the least square means were used $(P<0.05)$ among the treatments to identify the effective PL-SD combination.

Fig. (1). Schematic diagram of experimental design involving low and high fat chicken and turkey hotdog treatments to determine the effective combination of potassium lactate and sodium diacetate against surface inoculated Listeria monocytogenes. 


\section{RESULTS AND DISCUSSION}

\section{Proximate Analyses, pH and Water Activity of Hotdog Samples}

The percent moisture, fat, protein, residual nitrite, and $\mathrm{pH}$ of the hotdog samples determined on day zero are presented in Table 1 (A \& B). Protein content was significantly higher $(P<0.05)$ in chicken low fat hotdogs when compared to the other hotdog samples (high fat chicken, low and high fat turkey hotdogs) as it was prepared from skinless, boneless chicken breast. Furthermore, there were significant differences $(P<0.05)$ between chicken and turkey hotdogs in residual nitrite content $(\mathrm{ppm})$ with chicken hotdog samples having significantly higher $(P<0.05)$ nitrite than turkey samples (Table 1A).

The initial $\mathrm{pH}$ of the control samples (no lactates and diacetates) was 6.12 to 6.50 in low and high fat chicken and turkey hotdogs (Table 1B). Addition of antimicrobials at varying combination levels significantly $(P<0.05)$ reduced the $\mathrm{pH}$. Hotdog samples formulated with higher levels of PL $(2.0 \%$ or $3.0 \%)$ and $\mathrm{SD}(0.15 \%$ or $0.2 \%)$ reduced the $\mathrm{pH}$ in all meat and fat treatments (Table 1B). Addition of PL and $\mathrm{SD}$ at varying levels in hotdog formulations did not signifi- cantly $(P>0.05)$ reduce the water activity $\left(\mathrm{a}_{\mathrm{w}}\right)$ (data not shown) when compared to control samples suggesting that these samples provided favourable conditions for the growth of L. monocytogenes [22].

\section{Effect of PL and SD Combinations Against the Growth of Listeria monocytogenes:}

\section{In Low and High Fat Chicken Hotdog Samples}

Growth of L. monocytogenes on surface inoculated low and high fat chicken hotdog samples are presented in Fig. (2 A, B). In low and high fat chicken hotdogs, control samples that did not have PL and SD combination supported rapid growth of $L$. monocytogenes until spoilage $(\geq 9.0 \mathrm{log}$ cfu/g by 28 days of storage). However, incorporation of PL and SD at various combination levels achieved variable levels of growth inhibition of $L$. monocytogenes (Fig. 2 A, B). Treatments with $1.0 \%$ PL and $0.15 \%$ SD and $1.0 \%$ PL and $0.20 \%$ did not effectively inhibit the growth of $L$. monocytogenes due to low concentration of antimicrobials (lactates and diacetates) in the hotdog samples. Hotdogs formulated with higher levels of PL-SD combinations $(2-3 \%$ PL and $0.15-0.20 \% \mathrm{SD}$ ) demonstrated more growth inhibition compared to control. In chicken control samples, growth of

Table 1A. Percent Moisture, Protein, Fat and Residual Nitrite Determined in Low and High Fat Chicken and Turkey Hotdogs (No Lactate and Diacetate).

\begin{tabular}{|c|c|c|c|c|c|}
\hline Treatment & \multirow{2}{*}{ Fat } & Moisture & \multirow{2}{*}{ Protein (\%) } & \multirow{2}{*}{ Fat (\%) } & \multirow[t]{2}{*}{ Residual nitrite (ppm) } \\
\hline Meat & & $(\%)$ & & & \\
\hline \multicolumn{2}{|c|}{ Chicken Low } & $71.26^{\mathrm{a}}$ & $20.12^{\mathrm{a}}$ & $5.12^{\mathrm{b}}$ & $0.99^{\mathrm{a}}$ \\
\hline \multicolumn{2}{|c|}{ High } & $60.67^{\mathrm{b}}$ & $15.91^{\mathrm{b}}$ & $20.51^{\mathrm{a}}$ & $1.17^{\mathrm{a}}$ \\
\hline \multicolumn{2}{|c|}{ Turkey Low } & $69.24^{\mathrm{a}}$ & $15.56^{\mathrm{b}}$ & $5.08^{\mathrm{b}}$ & $0.59^{\mathrm{b}}$ \\
\hline \multicolumn{2}{|c|}{ High } & $58.24^{\mathrm{b}}$ & $14.57^{\mathrm{b}}$ & $20.34^{\mathrm{a}}$ & $0.47^{\mathrm{b}}$ \\
\hline
\end{tabular}

Values are the average of three replications.

Means followed by same superscripts in the same column are not significantly different $(P>0.05) .{ }^{a}$ denote highest number, ${ }^{b}$ denote 2 nd highest number, ${ }^{c} d e-$ note 3 rd highest number, and ${ }^{\mathrm{d}}$ denote lowest number.

Table 1B. pH Values Determined in Low and High Fat Chicken and Turkey Hotdog Samples

\begin{tabular}{|c|c|c|c|c|c|c|}
\hline Treatment & PL \% & SD\% & \multicolumn{2}{|c|}{ Chicken } & \multicolumn{2}{|c|}{ Turkey } \\
\hline T1 & 1.00 & 0.15 & $6.09^{\mathrm{b}}$ & $6.21^{\mathrm{a}}$ & $6.45^{\mathrm{a}}$ & $6.36^{\mathrm{a}}$ \\
\hline $\mathbf{T} 2$ & 1.00 & 0.20 & $6.05^{\mathrm{b}}$ & $6.00^{\mathrm{b}}$ & $6.30^{\mathrm{c}}$ & $6.25^{\mathrm{bc}}$ \\
\hline T4 & 2.00 & 0.20 & $5.94^{\mathrm{d}}$ & $5.93^{\mathrm{c}}$ & $6.26^{\mathrm{d}}$ & $6.12^{\mathrm{d}}$ \\
\hline T5 & 3.00 & 0.15 & $6.01^{\mathrm{c}}$ & $6.02^{\mathrm{b}}$ & $6.27^{\mathrm{cd}}$ & $6.26^{\mathrm{b}}$ \\
\hline T6 & 3.00 & 0.20 & $5.94^{\mathrm{d}}$ & $5.93^{\mathrm{c}}$ & $6.20^{\mathrm{e}}$ & $6.15^{\mathrm{d}}$ \\
\hline
\end{tabular}

Values are the average of three replications.

Means followed by same superscripts in the same column are not significantly different $(P>0.05) .{ }^{a}$ denote highest number, ${ }^{b}$ denote 2 nd highest number, ${ }^{c} d e-$ note 3 rd highest number, and ${ }^{\mathrm{d}}$ denote lowest number.

Treatments - (T; PL, SD): [(Control; 0, 0), (T1; 1.0, 0.10), (T2; 1.0, 0.20), (T3; 2.0, 0.15), (T4;2.0, 0.20), (T5; 3.0, 0.15) and (T6; 3.0, 0.20) 


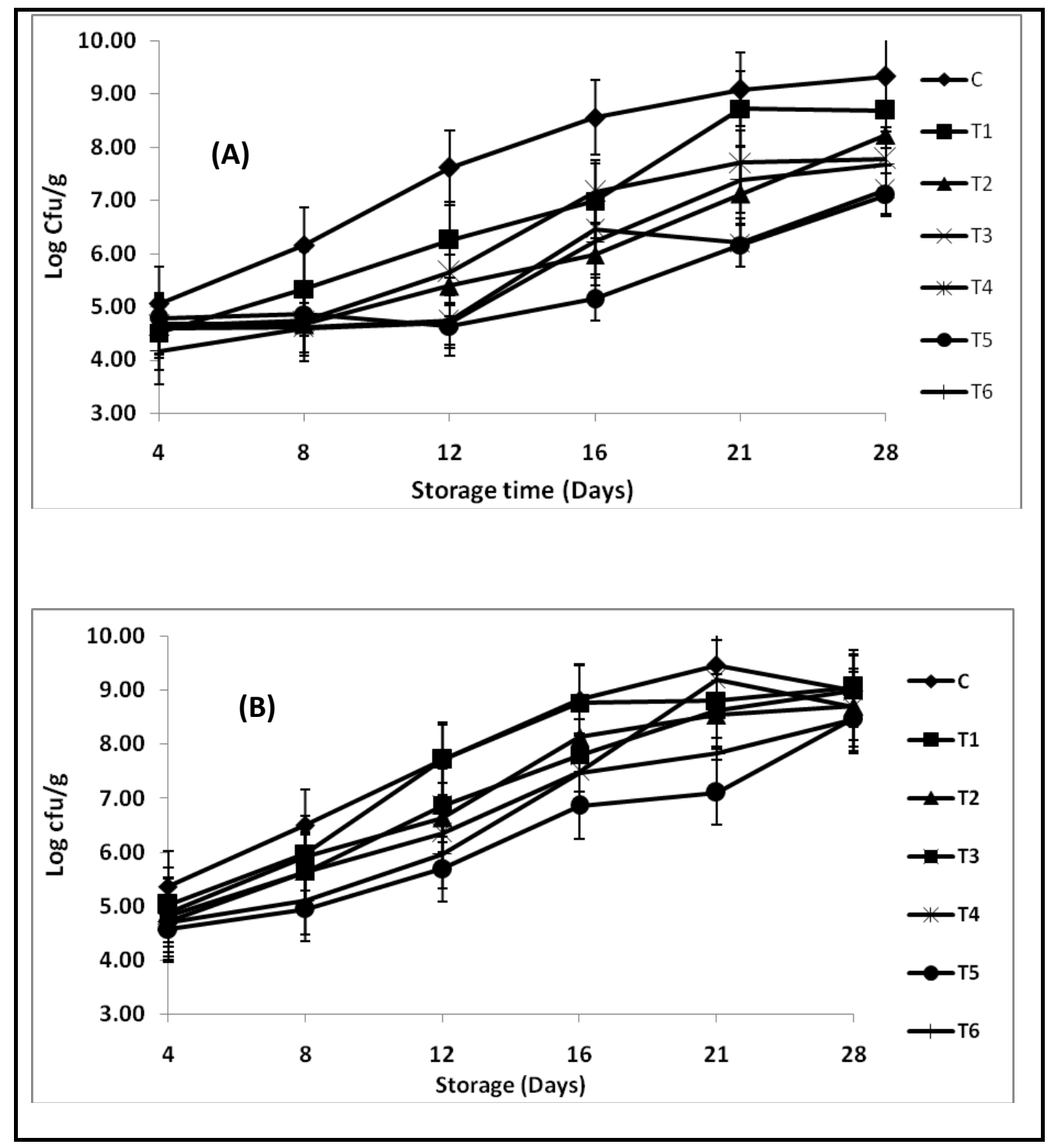

Fig. (2). (A \& B). Effect of Potassium Lactate (PL) and Sodium Diacetate (SD) combination against Listeria monocytogenes in (A) low fat and (B) high fat chicken hotdogs vacuum packed and stored at $4{ }^{\circ} \mathrm{C}$.

Data are mean log numbers (cfu/g) from three replications observed on $0,4,8,12,16,21$, and 28 days of storage.

Treatments - (T; PL\%, SD\%): [(Control; 0, 0), (T1; 1, 0.15), (T2; 1, 0.2), (T3; 2, 0.15), (T4; 2, 0.2), (T5; 3, 0.15), and (T6; 3, 0.2)].

Minimum level of detection is $100 \mathrm{cfu} / \mathrm{g}$.

L. monocytogenes was higher in high fat samples than low fat samples on all observation days. Considering the growth inhibition of $L$. monocytogenes, there were no significant differences $(\mathrm{P}>0.05)$ between low and high fat samples until $4^{\text {th }}$ day of storage $\left(4{ }^{\circ} \mathrm{C}\right)$. However, significant differences $(\mathrm{P}<0.05)$ in growth inhibition between low and high fat samples were apparent from $8^{\text {th }}$ day with higher growth inhibition values $(\log \mathrm{cfu} / \mathrm{g})$ in low fat samples. The most effective treatment in low and high fat chicken hotdog samples was the combination of $3.0 \%$ PL and $0.15 \%$ SD with 3.4 $\log \mathrm{cfu} / \mathrm{g}$ and $2.4 \log \mathrm{cfu} / \mathrm{g}$ growth inhibitions on the $16^{\text {th }}$ and $21^{\text {st }}$ days of storage, respectively. Higher growth inhibitions in low fat hotdog samples can be attributed to increased action of these antimicrobials in the water phase thus exhibiting the inhibitory activities against the growth of L. monocytogenes. These results were not consistent with findings of
$\mathrm{Hu}$ and Shelef [15] that inhibitory activities of lactates increased with fat content in the beaker sausages. Furthermore, previous studies conducted to determine the effect of fat content on the growth behaviour of L. monocytogenes in dairy foods such as cheese and yogurt reported that fat content had no effect on the growth pattern of L. monocytogenes [23]. These differences were may be due to the variation in the sensitivity of the strain used in dairy (Scott A vs V 7), product characteristics ( $\mathrm{pH}$, moisture, water activity), and model system matrix.

\section{In Low and High Fat Turkey Hotdog Samples}

Growth of L. monocytogenes in low and high fat turkey control hotdog samples over 28 days of storage at $4{ }^{\circ} \mathrm{C}$ are presented in Fig. (3 A, B). In low and high fat turkey samples, the initial (day 0) bacterial count was approximately 4.6 


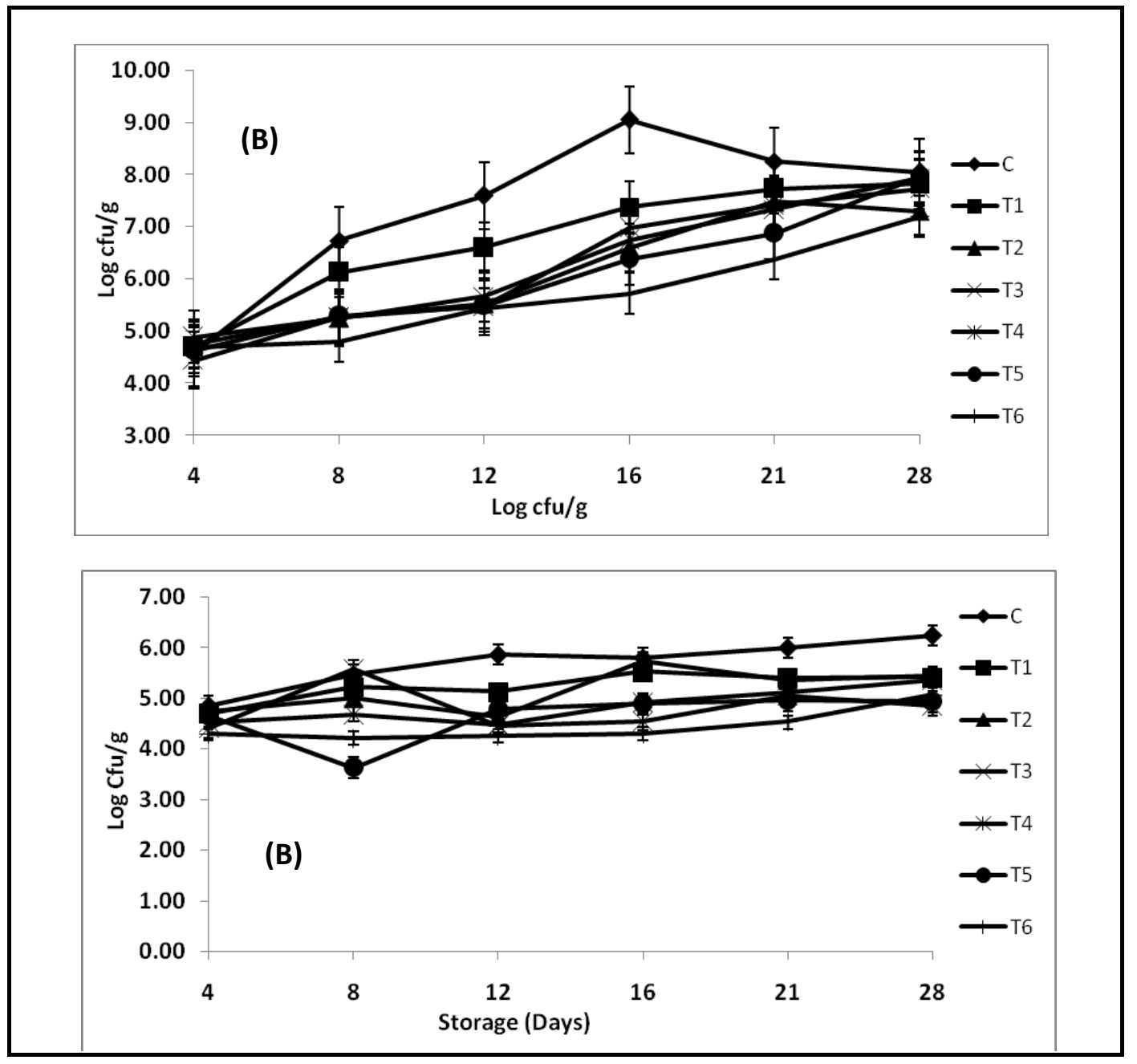

Fig. (3). (A \& B). Effect of Potassium Lactate (PL) and Sodium Diacetate (SD) combination against Listeria monocytogenes in (A) low fat and (B) high fat turkey hotdogs vacuum packed and stored at $4{ }^{\circ} \mathrm{C}$.

Data are mean log numbers ( $\mathrm{cfu} / \mathrm{g}$ ) from three replications observed on $0,4,8,12,16,21$, and 28 days of storage.

Treatments - (T; PL\%, SD\%): [(Control; 0, 0), (T1; 1, 0.15), (T2; 1, 0.2), (T3; 2, 0.15), (T4; 2, 0.2), (T5; 3, 0.15), and (T6; 3, 0.2)]Minimum level of detection is $100 \mathrm{cfu} / \mathrm{g}$.

$\log \mathrm{cfu} / \mathrm{g}$, while the maximum growth observed until spoilage by 28 days of storage at $4{ }^{\circ} \mathrm{C}$ was $8.1 \mathrm{log} \mathrm{cfu} / \mathrm{g}$ and 6.2 $\log \mathrm{cfu} / \mathrm{g}$, respectively. Interestingly, growth of L. monocytogenes in turkey high fat samples was low over 28 days of storage at $4{ }^{\circ} \mathrm{C}$. For example, in high fat control samples, $L$. monocytogenes population has grown from $4.7 \mathrm{log} \mathrm{cfu} / \mathrm{g}$ to $6.4 \log \mathrm{cfu} / \mathrm{g}$ by 28 days. Furthermore, in turkey high fat samples, treatments formulated with $2.0 \% \mathrm{PL}$ and $0.15 \% \mathrm{SD}$ or higher [(T; PL \%, SD \%): (T3; 2, 0.15), (T4; 2, 0.2), (T5; $3,0.15)$, and $(\mathrm{T} 6 ; 3,0.2)]$ demonstrated listeriostatic activity until 16 days of storage. However, this growth behaviour in high fat system was not consistent in the low fat samples. Considering the growth inhibition of L. monocytogenes, there were significant differences $(P<0.05)$ between low and high fat samples on all sampling days of storage. Growth inhibitions were higher $(P<0.05)$ in low fat turkey samples until $21^{\text {st }}$ day and thereafter, high fat samples exhibited higher growth inhibitions on $28^{\text {th }}$ day. The most effective treatment in low and high fat turkey hotdog samples was the combination of $3.0 \% \mathrm{PL}$ and $0.20 \%$ SD with $3.2 \mathrm{log} \mathrm{cfu} / \mathrm{g}$ and $1.6 \log \mathrm{cfu} / \mathrm{g}$ growth inhibition on $16^{\text {th }}$ and $12^{\text {th }}$ day of storage, respectively (Fig. 3 A, B).

Pathogen survivors following antimicrobial intervention (stressor: lactate and diacetate combination) stimulate their protective mechanisms [24]. However, inclusion of additional hurdles (storage temperature and vacuum packaging) that contribute to different mechanism(s) may be more effective in pathogen inhibition. Inhibition of $L$. monocytogenes in this study would be due to several factors. A combination of factors such as lactate and diacetate combinations, $\mathrm{pH}$, vacuum packaging (reduce the redox-potential), and storage temperature may have resulted in the varying antimicrobial activity of the treatments; suggesting that a multiple hurdle approach can inhibit the growth of L. monocytogenes during contamination [25]. Potassium lactate and sodium diacetate are widely used in combination in various meat and poultry products to enhance food safety and extend the shelf life $[11,13]$. Findings as discussed in previous sections were consistent with previous research findings that demonstrated varying levels of inhibition with PL-SD combination levels 
between 2 to $3 \% \mathrm{PL}$ and 0.15 to $0.2 \% \mathrm{SD}$ in various meat models [26,27].

These results also suggested that fat level has significant effect on the antimicrobial activity of the lactates and diacetates against the growth of $L$. monocytogenes. It is likely that high fat samples with lower growth inhibition could be due to the protective influence of fat (less water, pathogen cell protection) from the interaction of lactates and diacetates with the pathogen. This protective effect could either be due to physical protection of the bacterial cell or due to other types of interaction between fat in the meat and bacterial cell wall lipids [23]. In addition, in bi-phasic foods such as hotdogs (oil-in-water emulsion), lipid component of the food is vital in controlling the concentration of undissociated antimicrobial compounds in the aqueous phase. This is due to the lipophilic nature of the undisocciated organic acids; partitioning between aqueous and lipid compoenents of foods, and thus ultimately decreasing the concentration of undissociated organic acids (lactates and diacetates) in the aqueous phase [17].

Differences in the effective combinations of PL-SD determined in this study between meat and fat types against $L$. monocytogenes can also be attributed to the chemical composition and food structure, and thus may affect the bacterial attachment and growth of the pathogen [28]. Factors such as meat composition, type and level of unsaturated fatty acids, present in chicken and turkey meat may contribute to variances, as the unsaturated fatty acids are known to inhibit gram-positive foodborne pathogens such as L. monocytogenes [29,30].

\section{CONCLUSIONS}

Results of this study showed that, PL and SD when incorporated in hotdog formulations provided significant inhibition of $L$. monocytogenes growth at $4{ }^{\circ} \mathrm{C}$. Combination of $3.0 \% \mathrm{PL}$ and $0.15 \%$ or $0.20 \% \mathrm{SD}$ demonstrated effective growth inhibitions against $L$. monocytogenes than the other treatments. Fat content had a significant effect on the growth inhibition of L. monocytogenes as indicated by high fat samples having lower growth inhibition in chicken and turkey meat system. Current usage levels of PL $(\leq 2 \%)$ and diacetates combination in commercial hotdog formulations may not provide effective inhibition of $L$. monocytogenes when the product becomes contaminated. Therefore, other hurdle technologies in addition to using effective concentration levels of chemical antimicrobials need investigation to obtain minimum detectable levels of pathogens.

\section{CONFLICT OF INTEREST}

The authors confirm that this article content has no conflicts of interest.

\section{ACKNOWLEDGEMENTS}

Funding provided to conduct the research by the Food Safety Consortium is greatly appreciated. Authors would also like to thank Tyson Foods Inc. and Cargill Meat Solutions for donating chicken and turkey meat, respectively for this study.

\section{REFERENCES}

[1] Lianou A, Sofos JN. A review of the incidence and transmission of Listeria monocytogenes in ready-to-eat products in retail and food service environments. J. Food Prot 2007; 70: 2172-98.

[2] FDA. Quantitative assessment of relative risk to public health from foodborne Listeria monocytogenes among selected categories of ready-to-eat foods. In: Appendix 12: Cluster analysis for grouping of food categories 2003 .

[3] FDA. Performance standards for the production of processed meat and poultry products: proposed rule. Fed Reg 2001; 66: 12589-36.

[4] CDC. Public health dispatch: outbreak of listeriosis-Northeastern United States. MMWR 2002; 51: 950-1.

[5] Stekelenburg FK, Kant-Muermans MLT. Effects of sodium lactate and other additives in a cooked ham product on sensory quality and development of a strain of Lactobacillus curvatus and Listeria monocytogenes. Int J Food Microbiol 2001; 66: 197-203.

[6] Miller RK, Acuff GR. Sodium lactate affects pathogens in cooked beef. J Food Sci 1994; 59: 15-9.

[7] Hunter DR, Segal IH. Effect of weak acids on amino acid transport by Penicilium shrysogenum: evidence for proton or charge gradient as the driving force. J Bacteriol 1973; 113: 1184-92.

[8] Shelef LA, Addala L. Inhibition of Listeria monocytogenes and other bacteria by sodium diacetate. J Food Saf 1994; 14: 103-15.

[9] FDA. Food additives for use in meat and poultry products: sodium diacetate, sodium acetate, sodium lactate and potassium lactate. Fed Reg 2000; 65: 3121-3.

[10] Keeton JT. Formed and emulsion products. In Poultry Meat Processing. Sams AR Ed., Boca Raton, FL: CRC Press 2001; pp. 195226.

[11] Nuñez DGMT, Keeton JT, Ringer LJ. Effectiveness of acidic calcium sulfate with propionic and lactic acid and lactates as post processing dipping solutions to control Listeria monocytogenes on frankfurters with or without potassium lactate and stored vacuum packaged at 4.5. C J Food Prot 2004; 67: 915-21.

[12] Weber AJ. Palatability of roast beef and turkey injected with salts of various organic acids. M.S. thesis, Texas A\&M University, College Station 1997; TX.

[13] Knight TD, Castillo A. Effectiveness of Potassium lactate and sodium diacetate in combination with irradiation to control Listeria monocytogenes on frankfurters. J Food Sci 2007; 72: 26-30.

[14] Glass KA, Doyle MP. Fate of Listeria monocytogenes in processed meat products during refrigerated storage. Appl Environ Microbiol 1989; 55: 1565- 9 .

[15] $\mathrm{Hu} \mathrm{AC}$, Shelef LA. Influence of fat content and preservatives on the behavior of Listeria monocytogenes in beaker sausage. J Food Saf 1996; 16: 175-81.

[16] Seman JL, Borger AC, Meyer JD, Hall PA, Milkowski AL. Modeling of the growth of Listeria monocytogenes in cured ready-to-eat meat products by manipulation of sodium chloride, sodium diacetate, potassium lactate, and product moisture content. J Food Prot 2002; 65: 651-8.

[17] Brocklehurst TF, Wilson PDG. The role of lipids in controlling microbial growth. Grasas y Aceites 51 Fasc 2000; 1-2: 66-73.

[18] Leo A, Hansch C, Elkins D. Partition coefficients and their uses. Chem Rev 1971; 71, 5- 631.

[19] Komprda T, Sarmanova I, Zelenka J, Bakaj P, Fialova M, Fajmonova E. Effect of sex and age on cholesterol and fatty acid content in turkey meat. Arch Geflugelk 2002; 66: 263-73.

[20] Gadang VP, Hettiarachchy NS, Johnson MG, Owens C. Evaluation of antibacterial activity of whey protein isolate coating incorporated with nisin, grape seed extract, malic acid, and EDTA on a turkey Frankfurter system. J Food Sci 2008; 73: 389-94.

[21] Sivarooban T, Hettiarachchy NS, Johnson MG. Inhibition of Listeria monocytogenes using nisin with grape seed extract on turkey frankfurters stored at 4 and $10^{\circ} \mathrm{C}$. J Food Prot 2007; 70: 1017-20.

[22] Lado BH, Yousef AE. Characteristics of Listeria monocytogenes important to food processors. In: Ryser ET. Marth EH. Eds., Listeria, listeriosis and food safety, $3^{\text {rd }}$ ed. New York, NY: Marcel Dekker, Inc. 2007: pp. 157-213.

[23] Mehta A, Tahini SR. An evaluation of the microbiological safety of reduced-fat cheddar-like cheese. J Food Prot 1994; 57: 776-9.

[24] Ricke SC, Kundinger MM, Miller DR, Keeton JT. Alternatives to antibiotics: Chemical and physical antimicrobial interventions and foodborne pathogen response. Poult Sci 2005; 84: 667-75. 
[25] Buchanan RL, Golden MH, Whiting RC. Differentiation of the effects of $\mathrm{pH}$ and lactic or acetic acid concentration on the kinetics of Listeria monocytogenes inactivation. J Food Prot 1993; 56: 4748.

[26] Mbandi E, Shelef LA. Enhanced antimicrobial effects of combination of lactate and diacetate on Listeria monocytogenes and Salmonella spp. in beef bologna. Int J Food Microbiol 2002; 76, 191-8.

[27] Stekelenburg FK. Enhanced inhibition of Listeria monocytogenes in frankfurter sausage by the addition of potassium lactate and sodium diacetate mixtures. Food Microbiol 2003; 20: 133-7.
[28] Barmpalia IM, Koutsoumanis KP, Geornaras I, et al. Effect of antimicrobials as ingredients of pork bologna for Listeria monocytogenes control during storage at 4 or $10^{\circ} \mathrm{C}$. Food Microbiol 2005; 22: 205-11.

[29] Kabara JJ. Fatty acids and derivatives as antimicrobial agents. A review, In: JJ. Kabara Ed., The pharmacological effect of lipids Champaign, IL: AOCS, 1978; vol. I. p. 1-14.

[30] Mbandi E, Brywig M, Shelef LA. Antilisterial effects of free fatty acids and monolaurin in beef emulsions and hot dogs. Food Microbiol 2004; 21: 815-8.

(C) Perumalla et al.; Licensee Bentham Open.

This is an open access article licensed under the terms of the Creative Commons Attribution Non-Commercial License (http://creativecommons.org/licenses/by-nc/3.0/) which permits unrestricted, non-commercial use, distribution and reproduction in any medium, provided the work is properly cited. 